\title{
Characterisation and functional aspects of monoclonal antibodies specific for surface proteins of coagulase- negative staphylococci
}

\author{
C. P. TIMMERMAN, J. M. BESNIER*, L. DE GRAAF, R. TORENSMA, A. J. VERKLEY†, A. FLeER \\ and J. VERHOEF
}

GA Eijkman-Winkler Laboratory of Medical Microbiology, University of Utrecht, Heidelberglaan 100, G04 515, 3584 Utrecht, "Infectious Diseases Department, Bretonneau Hospital, 2 bis, Boulevard Tonnelle, 37044 Tours, France, †Department of Cell Biology and Genetics, State University of Utrecht, and $\ddagger$ University of Children's Hospital, "Het Wilhemina Kinderziekenhuis", University of Utrecht, The Netherlands

\begin{abstract}
Summary. Mouse monoclonal antibodies (MAbs) raised against whole cells of Staphylococcus epidermidis strain 354 were characterised morphologically and functionally. Nine MAbs showed strong reactivity with coagulase-negative staphylococci (CNS). Only two MAbs were specific for CNS; both belonged to the $\mathrm{IgG}_{1}$ subclass, and one, MAb 36.4, reacted only with the strain used for immunisation . In immunoblotting, both CNS-specific MAbs 36.3 and 36.4 reacted strongly with cell-wall protein bands of $220 \mathrm{Kda}$ of $S$. epidermidis strain 354 and weak reactivity was observed with a $110-\mathrm{Kda}$ band. MAb 36.3 reacted also with 220 $230 \mathrm{Kda}$ bands of two other S. epidermidis strains (291 and ATCC 35984) and a 160-180 Kda band of $S$. epidermidis strain 354. Only MAb 36.4 promoted phagocytosis of strain 354 by polymorphonuclear leucocytes (PMNL) and monocytes, whereas MAb 36.3 and the other MAbs lacked this activity. Opsonisation of $S$. epidermidis with MAb 36.4 in the presence of complement enhanced uptake by PMNL, but not by monocytes. Furthermore, S. epidermidis strain 354 opsonised with MAb 36.4 induced chemiluminescence of PMNL. Immuno-gold electronmicroscopy with both MAbs 36.3 and 36.4 demonstrated a homogeneous distribution of gold particles on the surface as well as close to the surface of S. epidermidis.
\end{abstract}

\section{Introduction}

Coagulase-negative staphylococci (CNS), particularly strains of Staphylococcus epidermidis, are increasingly recognised in infections related to foreign bodies such as intravascular ${ }^{1-3}$ and peritoneal dialysis catheters, ${ }^{4,5}$ prosthetic joints and heart valves. ${ }^{6}$ Pathogenesis of infections related to such foreign bodies is still unclear although surface hydrophobicity and the production of extracellular slime are probably involved in adherence of CNS to biomaterials. Treatment of CNS with proteolytic enzymes resulted in reduced adherence to catheter segments and decreased hydrophobicity, suggesting a role for hydrophobic surfaceexposed proteins in adherence. ${ }^{7}$ Moreover, recent evidence indicates that surface hydrophobicity of CNS is important in complement-dependent opsonisation. ${ }^{8}$ Both of these results suggested an important role for the hydrophobic parts of exposed proteins of CNS.

In the studies reported here we have characterised two monoclonal antibodies (MAbs) specific for surface proteins of CNS. We have examined opsonisation of

Received 7 Sep. 1990; accepted 1 Oct. 1990. one $S$. epidermidis strain by a MAb, as measured by the ability to elicit chemiluminescence from human polymorphonuclear (PMNL) and monocytes, and the reactivity of MAbs with surface structures of strains of $S$. epidermidis by immuno-gold electronmicroscopy (EM).

\section{Materials and methods}

\section{Bacterial strains}

Forty-three CNS isolates (S. epidermidis) from patients with catheter-related bacteremia, two CNS strains from the American Type Culture Collection (S. epidermidis ATCC 35984 and $S$. hominis ATCC 35982), two other strains of $S$. hominis and six strains of S. aureus (Cowan I, EMS, Wood 46, H+, H-, no. $304)^{9}$ were used in our experiments. All strains were lyophilised and stored at $-70^{\circ} \mathrm{C}$.

For specificity tests, 10 strains of enterobacteria (Acinetobacter anitratus, Citrobacter diversus, C. freundii, Enterobacter cloacae, Escherichia coli, Klebsiella pneumoniae, Proteus mirabilis, P. vulgaris, Serratia marcescens) were used. 


\section{Monoclonal antibodies}

MAbs were raised against a clinical isolate of $S$. epidermidis (strain 354) by the method of Kohler and Milstein ${ }^{10}$ with minor modifications. Briefly BALB/c mice were immunised intraperitoneally (i.p.) with $200 \mu$ of a suspension of live cells $\left(5 \times 10^{7} \mathrm{cfu}\right)$ in four injections. An intravenous booster dose of $200 \mu \mathrm{l}(5 \times$ $10^{7} \mathrm{cfu}$ ) of the suspension was given 3 days before the fusion. Spleen cells were fused with cells from a mouse myeloma cell line, SP 2/0-Ag $14^{12}$ in a ratio of 5:1. The hybridomas were screened for antibody activity against intact cells of strains of $S$. epidermidis by ELISA; 96-well microtitration plates were coated overnight in phosphate-buffered saline (PBS, $\mathrm{pH} 7 \cdot 4$ ) with bacteria. For production of ascites, selected hybridomas $\left(5 \times 10^{5}\right.$ cells $)$ were injected i.p. into pristane-(Janssen Chemica, Beerse, Belgium)-primed $\mathrm{BALB} / \mathrm{c}$ mice. MAbs were purified by high performance liquid chromatography (HPLC) on an $\mathrm{ABx}$ column (J. T. Baker Chemical Company, Philipsburg, NJ, USA). Cross-reactivity was determined by ELISA with $S$. hominis, $S$. aureus and enterobacterial strains. An OD value $\geqslant 0.5$ was considered to be a positive result.

\section{Preparation of staphylococcal proteins}

Bacteria were grown overnight at $37^{\circ} \mathrm{C}$ in Nutrient Broth (Difco). Cells were washed in PBS (pH 7.4) and harvested by centrifugation at $3000 \mathrm{~g}$ for $15 \mathrm{~min}$. Bacteria were resuspended in $1 \mathrm{ml}$ of PBS containing $100 \mu \mathrm{g}$ of lysostaphin (Sigma) and incubated at $37^{\circ} \mathrm{C}$ for $4 \mathrm{~h}$ in a rotary mixer $(24 \mathrm{rpm})$. To inhibit proteolytic activity from enzymes released by the bacteria during lysostaphin treatment, phenylmethylsulphonylfluoride (PMSF; Sigma) was added to give a final concentration of $1 \mathrm{mM}$. After centrifugation at $14000 \mathrm{~g}$ for $15 \mathrm{~min}$ the supernate containing the staphylococcal polypeptides was held at $-20^{\circ} \mathrm{C}$ in siliconised eppendorf tubes. Protein concentration was measured by Bradford's method. ${ }^{13}$ The sample was lyophilised and adjusted to a protein concentration of $300 \mu \mathrm{g} / \mathrm{ml}$ for further tests.

\section{$S D S-P A G E$ and immunoblotting}

After lyophilisation, staphylococcal proteins were dissolved in sample buffer-sodium dodecyl sulphate (SDS) $4 \% \mathrm{w} / \mathrm{v}$, dithiothreitol $5 \% \mathrm{w} / \mathrm{v}$, glycerol $40 \% \mathrm{w} / \mathrm{v}$, and bromophenol blue in $1 \mathrm{M}$ Tris/ $\mathrm{HCl}$ buffer-and boiled for $5 \mathrm{~min} ; 10 \mu \mathrm{g}$ of protein per $30 \mu \mathrm{l}$ was applied to each well for electrophoresis in a polyacrylamide $12 \%$ running gel with a $4 \%$ stacking gel according to the method of Laemmli. ${ }^{14}$ The gel was stained with Coomassie Brilliant Blue R 250 (CBB; Fluka Chemicals).

For immunoblotting staphylococcal proteins were separated in a polyacrylamide $7 \%$ gel and transferred from the gel on to nitrocellulose paper (pore diameter
$0.45 \mu \mathrm{m}$; Schleicher and Schuell, Dassel, Germany). Free protein-binding sites on the nitrocellulose were saturated by incubation overnight in blocking buffer containing Tween $200.10 \%$ and gelatine $3 \%$ in PBS at $4^{\circ} \mathrm{C}$. After a further $1 \mathrm{~h}$ at $37^{\circ} \mathrm{C}$ and washing three times in PBS-Tween $200.1 \%$, the nitrocellulose paper was cut into strips. Each strip was incubated at $37^{\circ} \mathrm{C}$ for $1.5 \mathrm{~h}$ in $2 \mathrm{ml}$ of MAb 36.4 ( 1 in 40000 ), MAb 36.3 (1 in 5000) or rabbit hyperimmune serum (1 in 1000) in PBS. After washing three times in PBS, the strips were incubated at $37^{\circ} \mathrm{C}$ for $1.5 \mathrm{~h}$ in $2 \mathrm{ml}$ of peroxidaseconjugated affinity purified goat anti-mouse IgG antibody (Cappel, $\mathrm{n}$ 3611-0081) (1 in 2500) or antirabbit IgG antibody ( 1 in 5000) in PBS. After washing four times, each strip was incubated in $2 \mathrm{ml}$ of substrate solution $-3^{\prime}, 3^{\prime}, 5^{\prime}, 5^{\prime}$-tetramethylbenzidine (Sigma T-2885) $0.2 \% \mathrm{w} / \mathrm{v}$ and sodium dioctylsulphosuccinate (Serva 20540) 0.8\% w/v dissolved in $10 \mathrm{ml}$ of ethanol $96 \%$ in a water-bath at $56^{\circ} \mathrm{C}$ was mixed with $30 \mathrm{ml}$ of buffer (pH 5) containing $100 \mathrm{~mm}$ citric acid and $200 \mathrm{~mm}$ disodium hydrogen phosphate dihydrate; $20 \mu \mathrm{l}$ of $\mathrm{H}_{2} \mathrm{O}_{2} 30 \%$ was added just before use. The reaction was stopped by rinsing the nitrocellulose strip in tap-water.

\section{Immuno-gold labelling for electronmicroscopy}

Immuno-gold labelling was performed as described by Voorhout et al. ${ }^{15} S$. epidermidis cells were fixed in growth medium by adding an equal volume of glutaraldehyde $0.5 \%$, paraformaldehyde $2 \%$ in PBS, $\mathrm{pH} 7 \cdot 4$, and left for $1 \mathrm{~h}$ at room temperature. The cells were centrifuged at $2000 \mathrm{~g}$ for $10 \mathrm{~min}$, washed with $50 \mathrm{mM}$ glycine in PBS (PBS/Gly) and a solution of BSA $0.5 \%$ and gelatin $0.1 \%$ in PBS (PBG) for $1 \mathrm{~h}$ each. After centrifugation, $50 \mu$ lof the cell pellet was resuspended in $450 \mu \mathrm{l}$ of PBG and incubated with MAbs for $1 \mathrm{~h}$ at room temperature or overnight at $4^{\circ} \mathrm{C}$. Then the cells were rinsed five times with PBG (10 min each) and incubated with $20 \mu \mathrm{l}$ of swine antimouse (SWAM) secondary antibody (Nordic, Tilburg, The Netherlands) $10 \mathrm{mg} / \mathrm{ml}$. Finally the cells were incubated under saturating conditions for $1 \mathrm{~h}$ with protein A-gold ( $12 \mathrm{~nm}$ diameter) diluted to $\mathrm{OD}_{520} 1 \cdot 0$. The incubated cells were rinsed thoroughly five times with PBG, four times with distilled water and then attached to a nickle grid covered with a carbon coated formvar film. After rinsing and drying, the cells were examined with a Philips EM-420 electronmicroscope at $80 \mathrm{kV}$.

\section{Isolation of human PMNL and monocytes}

Human PMNL were isolated from heparinised blood by dextran sedimentation and Ficoll-Paque (Pharmacia, Sweden) density gradient centrifugation. Residual red-blood cells were lysed by hypotonic shock. The resulting PMNL were washed once and suspended in Hanks's Balanced Salts Solution (HBSS) 
supplemented with gelatin (HBSS-gel). Mononuclear cells were isolated by the method of Böyum. ${ }^{16}$

\section{Phagocytosis assay}

Bacteria were radioactively labelled by overnight incubation in Mueller-Hinton Broth (Difco) containing methyl $-{ }^{3}[\mathrm{H}]$ thymidine (specific activity $5 \cdot 0 \mathrm{Ci}$ / mmol; Radiochemical Centre, Amersham) $2 \mu \mathrm{Ci} / \mathrm{ml}$. Opsonisation and phagocytosis assays were performed as described previously. ${ }^{17,18}$

\section{Opsonins}

Human pooled serum (HPS) was obtained from 20 healthy adult donors and stored in 1-ml volumes at $-70^{\circ} \mathrm{C}$. The source of complement was serum from a child with agammaglobulinaemia with a normal total haemolytic complement activity of the classical and alternative pathways $(\operatorname{IgG}<0.01 \mathrm{~g} / \mathrm{L})$.

\section{Chemiluminescence assay}

Luminol-dependent chemiluminescence (CL) was monitored with an automatic Packard Picolite Luminometer (Packard Instruments, Brussels, Belgium). Opsonised $S$. epidermidis cells $\left(2.5 \times 10^{8} / \mathrm{ml}\right)$ were mixed with luminol (final concentration $1 \times 10^{-5} \mathrm{M}$ ) and incubated with $10^{7} \mathrm{PMNL} / \mathrm{ml}$ in a total volume of $2 \mathrm{ml}$ of HBSS-gel. Controls contained PNML without bacteria. Experiments were performed at $37^{\circ} \mathrm{C}$ in the dark and counts were recorded for $6 \mathrm{~s}$ over a $30-$ min period.

\section{Statistical analysis}

The differences between sets of results were assessed by Student's $t$ test; differences were considered to be significant when $\mathrm{p} \leqslant 0 \cdot 05$.

\section{Results}

\section{Reactivity of $M A$ Abs with intact bacteria}

MAbs raised in three separate fusions were tested for reactivity with several gram-positive and gramnegative bacterial species. The results of the screening are shown in the table. Nine MAbs were selected that reacted strongly with intact cells of CNS. MAbs of the IgM-class (nos. 17.15, 23.23 and 36.2) showed crossreactivity with $S$. aureus strains; MAbs 17.15 and 36.2 also reacted with several gram-negative species. None of the IgG MAbs cross-reacted with any gram-negative bacteria. MAb 36.3 subclass $\operatorname{IgG}_{1}$, reacted with most ( 28 of 44 ) of the CNS strains, whereas MAb 36.4 was highly specific for $S$. epidermidis strain 354 used for immunisation and did not show any reactivity with other CNS strains.

\section{SDS-PAGE and immunoblotting}

SDS-PAGE of $S$. epidermidis $(\mathrm{n}=6), S$. hominis (2), and $S$. aureus (3) strains showed multiple (25-35) bands $21-230 \mathrm{Kda}$, with a clustering of bands between 40 and $100 \mathrm{Kda}$ (fig. 1). Clear differences between the various $S$. epidermidis strains are apparent, either in the number of bands, their position in the gel or in the intensity of one or more bands. However, immunoblot analysis of nine CNS strains with rabbit hyperimmune serum, showed bands that were shared (fig. 2); two bands of $c .55$ and $c .65 \mathrm{Kda}$ were present in all strains studied.

Immunoblotting with MAbs 36.4 and 36.3 revealed reactivity with a band of $220-230 \mathrm{Kda}$ (fig. $3 \mathrm{a}$ and $\mathrm{b}$ ), and also with a $110-\mathrm{Kda}$ band. The latter reactivity disappeared when PMSF was used during preparation of the cell-wall polypeptides. Pre-incubation of nitrocellulose paper with rabbit IgG did not influence binding of MAbs 36.3 and 36.4 with the $110-\mathrm{Kda}$ band, indicating a specific binding at this site. Furthermore, the immunoblots confirmed the exclu-

Table. Reactivity of MAbs with clinical isolates of S. epidermidis and other bacterial species, as determined in ELISA

\begin{tabular}{ll|cccc}
\hline & & \multicolumn{4}{|c}{ Number of strains reactive with MAb } \\
\cline { 3 - 6 } $\begin{array}{c}\text { MAb } \\
\text { no. }\end{array}$ & Class & $\begin{array}{c}\text { S. epidermidis } \\
(\mathrm{n}=17 \text { or } 44)^{*}\end{array}$ & $\begin{array}{c}\text { S. hominis } \\
(\mathrm{n}=3)\end{array}$ & $\begin{array}{c}\text { S. aureus } \\
(\mathrm{n}=6)\end{array}$ & $\begin{array}{c}\text { enterobacteria } \\
(\mathrm{n}=10)\end{array}$ \\
\hline 17.5 & $\mathrm{IgG}_{3}$ & $13 / 17$ & 3 & 6 & 0 \\
23.12 & $\mathrm{IgG}_{1}$ & $13 / 17$ & 3 & 5 & 0 \\
23.42 & $\mathrm{IgG}_{2 \mathrm{a}}$ & $10 / 17$ & 0 & 5 & 0 \\
36.1 & $\mathrm{IgG}_{2 \mathrm{~b}}$ & $12 / 17$ & 1 & 2 & 0 \\
36.3 & $\mathrm{IgG}_{1}$ & $28 / 44$ & 2 & 0 & 0 \\
36.4 & $\mathrm{IgG}_{1}$ & $1 / 44$ & 0 & 0 & 0 \\
17.15 & $\mathrm{IgM}_{23.23}$ & $17 / 17$ & 3 & 6 & 9 \\
36.2 & $\mathrm{IgM}$ & $17 / 17$ & 2 & 6 & 9 \\
\hline
\end{tabular}




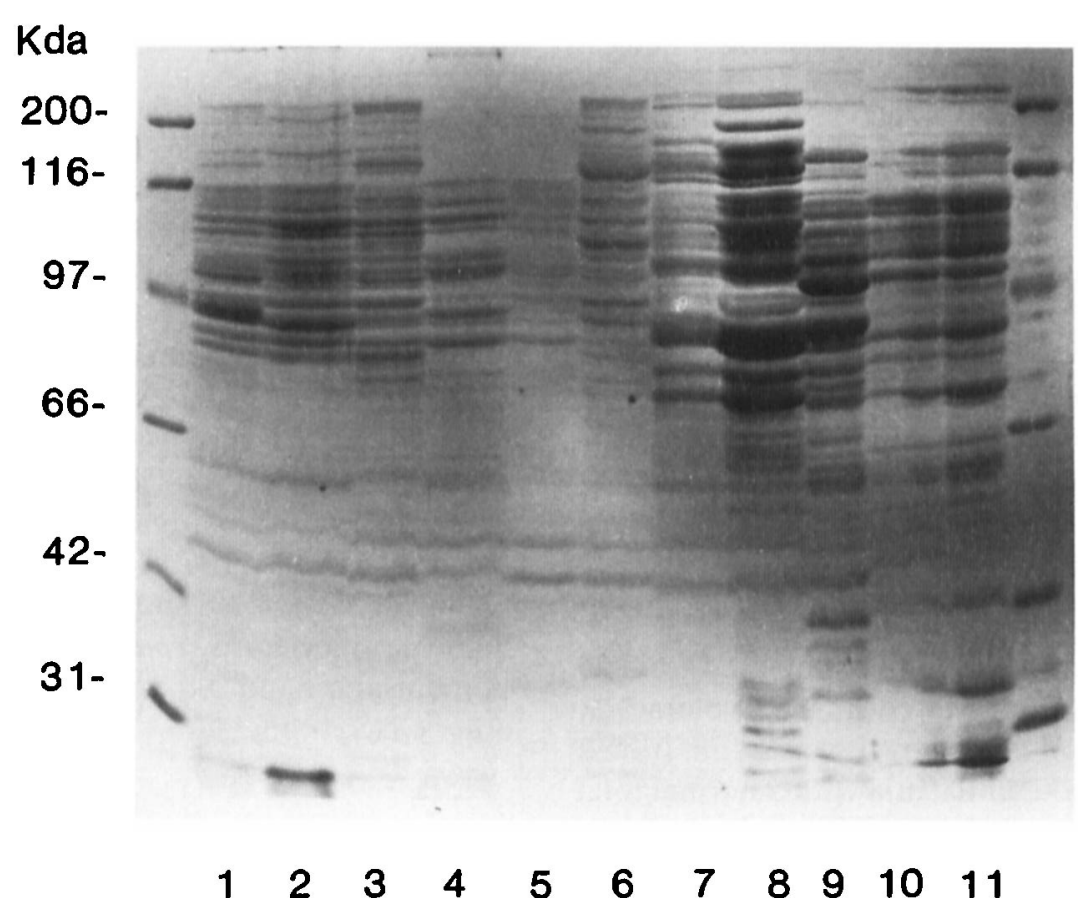

Fig. 1. SDS-PAGE of six S. epidermidis strains (lanes 1-6: strains 354, 291, ATCC 35984, 463, 348 and 412), two $S$. hominis strains (lanes 7 and 8: strains 268 and ATCC 35982) and three $S$. aureus strains (lanes 9-11).

sive reactivity of MAb 36.4 with the strain used for immunisation ( $S$. epidermidis strain 354 ), whereas MAb 36.3 also reacted strongly with protein bands of c. 220-230 Kda of two other S. epidermidis strains (291 and ATCC 35984) and a band of 160-180 Kda of $S$. epidermidis strain 463 . MAb 36.3 also reacted with the $S$. hominis test strain in ELISA, but not in immunoblotting. Strains that did not react with either MAb in
ELISA, also failed to show any reaction with these MAbs in immunoblots.

\section{Phagocytosis and chemiluminescence}

Opsonisation of $S$. epidermidis strain 354 with MAb 36.4 showed significantly greater phagocytosis $(\mathrm{p}<$ 0.01 ) by PMNLs $(19 \%$ SD $6.5 \%)$, than when the

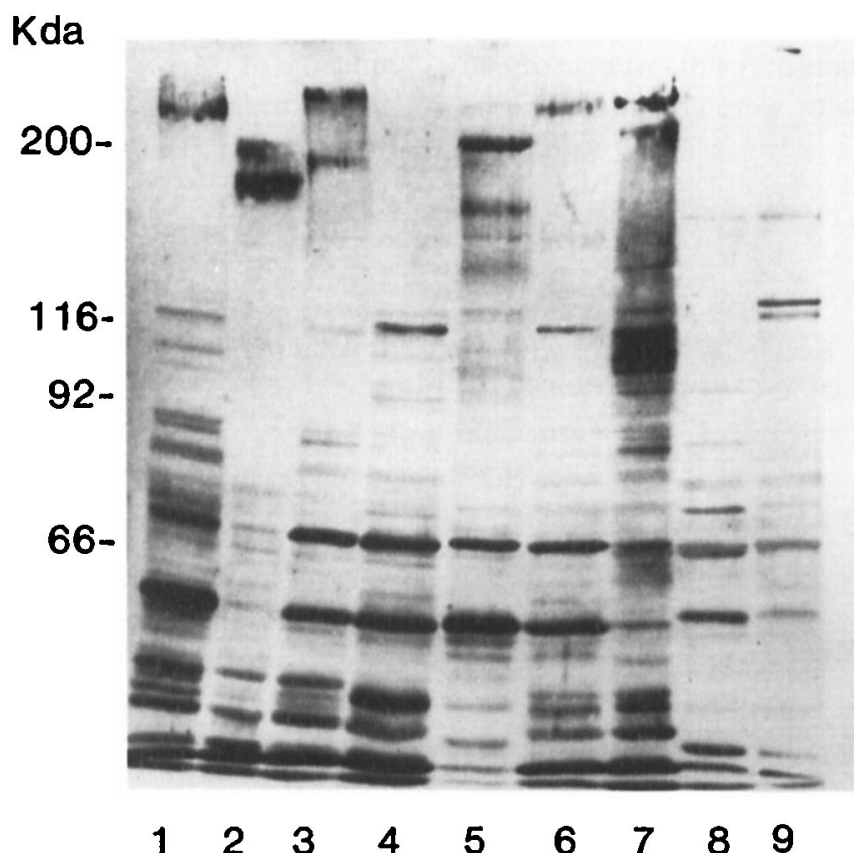

Fig. 2. Immunoblots of nine CNS strains after incubation with rabbit hyperimmune serum. Lanes 1-7: S. epidermidis strains ATCC 35984, 463, 291, 412, 501, 348 and 354; lanes 8 and 9: S. hominis strains ATCC 35982 and 268. 

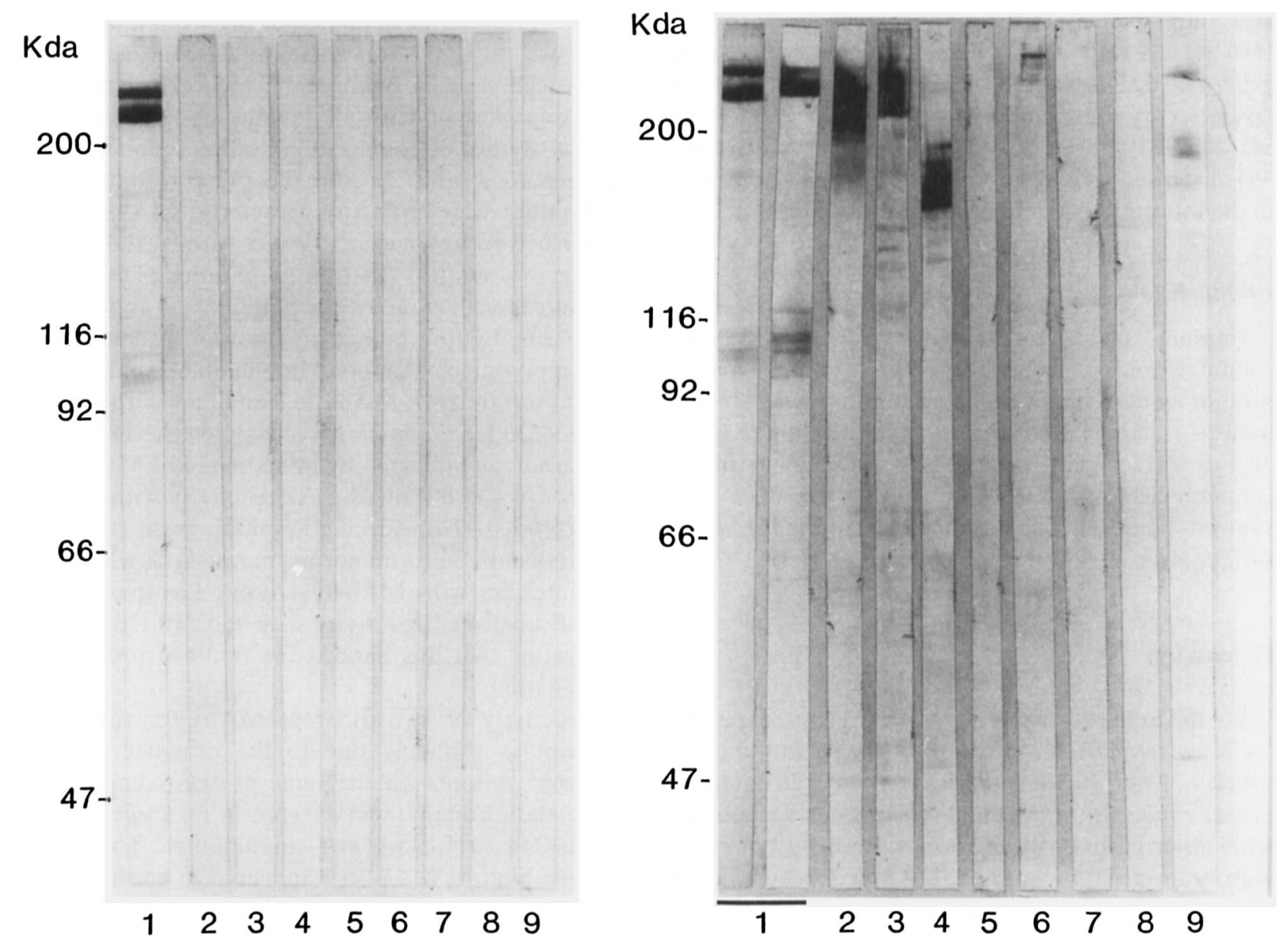

Fig. 3. Immunoblots of nine CNS strains: (a) after incubation with MAb 36.4, which reacted only with $S$. epidermidis strain 354 (lane 1); (b) after incubation with MAb 36.3 showing reactivity with a high mol. wt band of $S$. epidermidis strain 354 (lanes 1 and 1 a); lanes $2-9, S$. epidermidis strains 291, ATCC 35984, 463, 348, 412 and 501.

bacteria were opsonised with HPS $1 \%(13.8 \%$ SD $1 \cdot 2 \%$ ) or were unopsonised (4.7\% SD 2.3\%) (fig. 4). Complement-mediated opsonophagocytosis was markedly enhanced in the presence of MAb $36.4(49 \%$ SD $7.7 \%)$ than with complement alone $(6 \cdot 1 \% \mathrm{SD}$ $2.0 \%)$.

The same experiments performed with human monocytes showed enhanced phagocytosis of $S$.

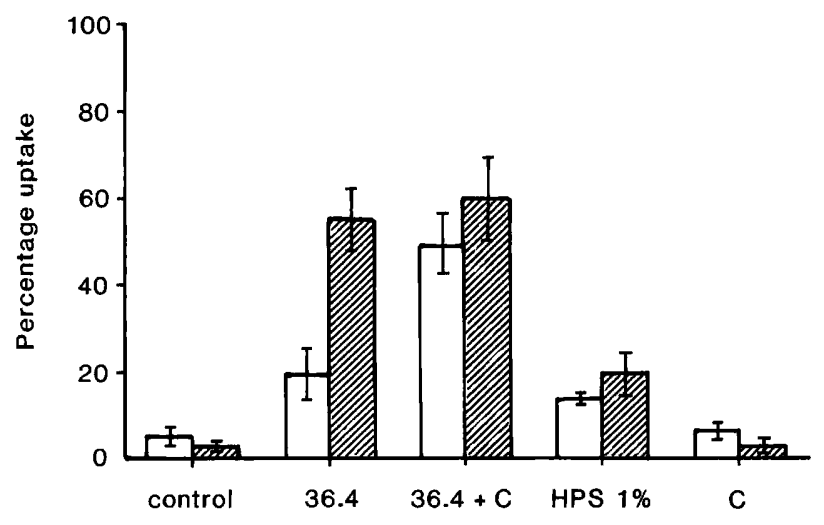

Fig. 4. Phagocytosis of $S$. epidermidis strain $354\left(2.5 \times 10^{8} \mathrm{cfu} / \mathrm{ml}\right)$ by human PMNL $(\square)\left(5 \times 10^{6} \mathrm{ml}\right)$ or human monocytes $\left(5 \times 10^{6} /\right.$ $\mathrm{ml})(\mathbb{G})$ after opsonisation with MAb 36.4 alone and with complement $(36 \cdot 4+C)$. Controls were $S$. epidermidis strains unopsonised and after opsonisation with human pooled serum (HPS 1\%) and complement $(\mathrm{C})$. Bar represents SD. epidermidis strain 354 opsonised with MAb 36.4 both with $(60 \%$ SD $9.7 \%)$ and without $(55 \%$ SD $7.3 \%)$ complement. MAb 36.3 and all other MAbs tested failed to promote uptake of $S$. epidermidis strain 354 (fig. 4).

Opsonisation of S. epidermidis strain 354 with MAb 36.4 resulted in an increased generation of $C L$ by human PMNLs (210 SD $120 \times 10^{4} \mathrm{cpm}$ ) (fig. 5). Incubation of $S$. epidermidis opsonised with MAb 36.4

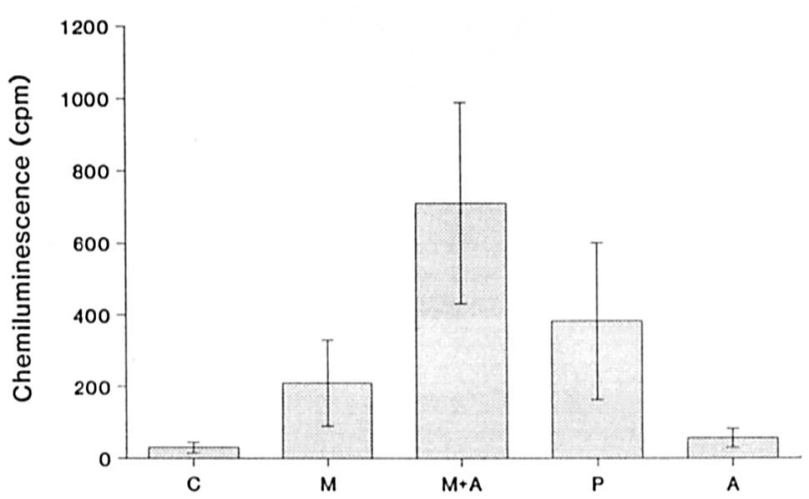

Fig. 5. Luminol-enhanced $C L$ of human PMNLs after incubation with S. epidermidis strain 354 opsonised with MAb 36.4 alone (M) and with complement $(M+A)$. Controls were unoponised strains (C) and strains opsonised with $5 \%$ human pooled serum $(\mathrm{P})$ or complement (A). Bar represents SD. 
and complement with PMNL displayed increased CL $\left(710 \mathrm{SD} 279 \times 10^{4} \mathrm{cpm}\right)$, which was greater than that generated by HPS $5 \%\left(382 \mathrm{SD} 219 \times 10^{4} \mathrm{cpm}\right)$. Bacteria opsonised by complement alone generated less CL ( 57 SD $26 \times 10^{4} \mathrm{cpm}$ ). In contrast, $S$. epidermidis strain 354 opsonised with MAb 36.3 or other MAbs described in the table failed to induce a metabolic burst.

\section{Immuno-gold electronmicroscopy}

Immunolabelling of $S$. epidermidis strains with colloidal gold particles complexed with $S$. aureus protein A showed homogeneous binding of MAb 36.4 to the surface of the cell (fig. 6). Some binding of MAb 36.4 to extracellular material was also demonstrated. Immuno-electronmicroscopy with MAb 36.3 also showed homogeneous localisation of the MAb to surface structures and extracellular material.

\section{Discussion}

We have characterised two MAbs that were specific for $S$. epidermidis strains. Both belonged to the $\mathrm{IgG}_{1}$ subclass. MAb 36.3 reacted strongly with 28 out of 44 S. epidermidis strains, without showing cross-reactivity with other gram-positive species, and did not react with gram-negative species. MAb 36.4 reacted only with the strain used for immunisation.

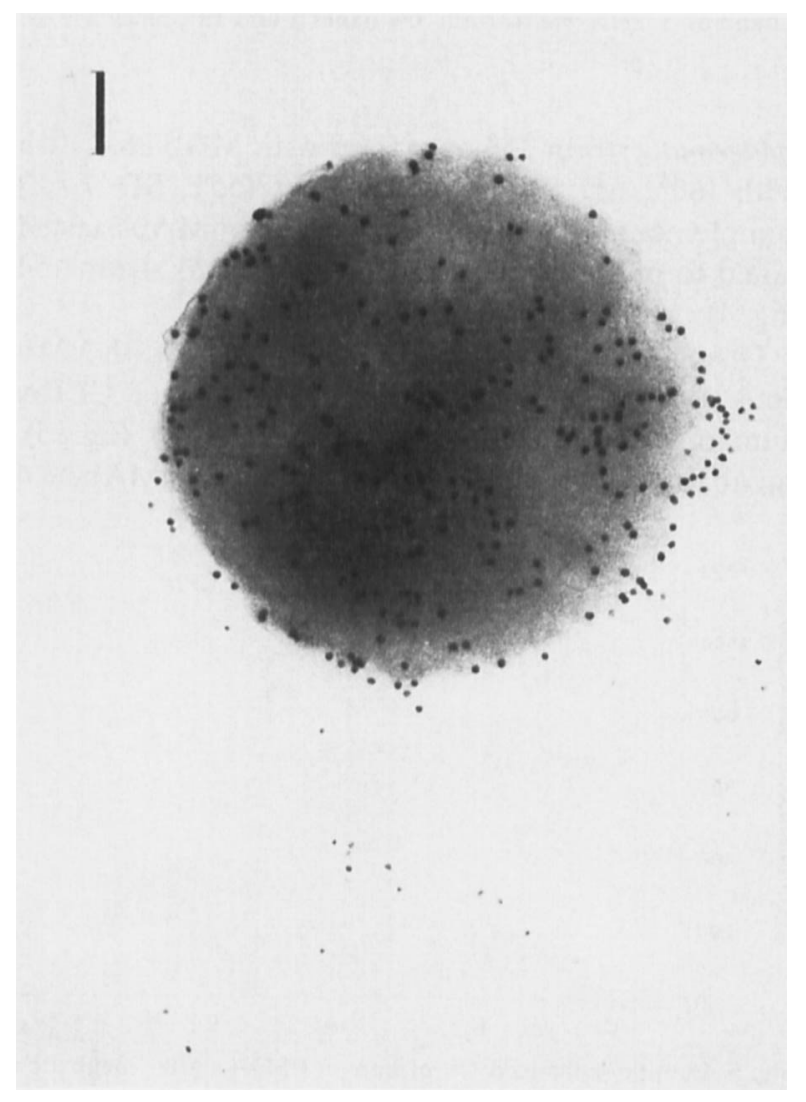

Fig. 6. Immuno-gold electronmicroscopy of S. epidermidis strain 354 incubated with MAb 36.4 and labelled with SWAM and protein Agold. Bar $100 \mathrm{~nm}$.
SDS-PAGE and immunoblotting techniques have been used by some workers to evaluate the usefulness of the technique for typing staphylococci by determining the pattern of cell-wall proteins, and in epidemiological studies of colonisation and infection with $S$. epidermidis strains. ${ }^{19,20}$ In the present study these techniques were used to characterise MAbs raised against live staphylococci. We confirmed the results of previous studies ${ }^{20}$ that the preparation of staphylococcal cell-wall proteins for SDS-PAGE and immunoblotting by lysostaphin digestion of bacterial cells is a reproducible method. Immunoblot analysis revealed reactivity of MAbs 36.3 and 36.4 with a band of $220-230 \mathrm{Kda}$, apparently located on the surface of the strains as indicated by immuno-gold EM studies. Both MAbs also showed weak reactivity with a band of $c .110 \mathrm{Kda}$ Non-specific Fc-binding was ruled out by pre-incubation with normal mouse IgG, which did not interfere with MAb reactivity. Treatment with PMSF abolished reactivity with the 110-Kda band, suggesting that this band is the result of proteolytic degradation.

Reactivity of two different MAbs for the same proteins is probably due to the presence of two different epitopes on the same protein complex. In these studies, one of them was specific for $S$. epidermidis strain 354 in ELISA and immunoblot. The other epitope binding MAb 36.3 appeared to be shared by other $S$. epidermidis strains $(291,463$ and ATCC 35984). Furthermore, MAb 36.3 appeared to detect mol.-wt variants, because reactivity with $S$. epidermidis strains 463 was with a $160-180-\mathrm{Kda}$ band. Reactivity of one MAb with bands of different mol. wt could be explained either by size heterogeneity of the same protein because of lysostaphin treatment, or to proteolytic digestion of a common protein, or to the presence of variable amounts of associated molecules such as oligosaccharides or fragments of peptidoglycan, in the various strains.

With the phagocytosis assay, we found increased uptake of $S$. epidermidis strain 354 by human PMNLs and monocytes after opsonisation with MAb 36.4, whereas opsonisation with other MAbs reactive with CNS did not promote uptake. Opsonisation by complement and MAb 36.4 enhanced bacterial uptake by PMNLs. Complement alone did not promote phagocytosis of $S$. epidermidis strain 354 . It is likely that uptake of $S$. epidermidis opsonised with murine $\mathrm{IgG}_{1}$ MAb 36.4 is mediated by the $\mathrm{Fc} \gamma \mathrm{R} 2$ receptors of human PMNL, whereas uptake by human monocytes is probably mediated by $F c \gamma R 2$ as well as $F c \gamma R 1 .{ }^{1}$ The presence on monocytes of both $F c \gamma R 1$ and $F c \gamma R 2$, which show respectively low and high affinity for murine $\mathrm{IgG}_{1}$ immunoglobulins, might explain the higher uptake of $S$. epidermidis strain 354 opsonised with MAb 36.4 in the absence of complement by monocytes compared to PMNLs. Opsonisation of $S$. epidermidis was enhanced in the presence of complement, but complement alone did not promote uptake by PMNLs as well as by monocytes. Clark and 
Easmon $^{21}$ also found that complement did not promote interaction of CNS with human PMN. In contrast, Van Bronswijk et al. ${ }^{8}$ found that phagocytosis of CNS by human PMNL was promoted by complement alone, although this required extension of the opsonisation time to $90 \mathrm{~min}$.

Opsonisation of $S$. epidermidis strain 354 with $\mathrm{MAb}$ 36.4 also stimulated PNML CL. Addition of complement markedly enhanced the $\mathrm{CL}$, whereas opsonisation by complement alone did not result in metabolic activation of PMNL. Together these results indicate that MAb 36.4, when bound to the staphylococcal surface, is capable of binding the phagocyte Fcreceptor and of activating complement.

Immuno-gold electronmicroscopy showed a homogeneous distribution of binding sites for MAbs 36.4

\section{References}

1. Peters G, Locci R, Pulverer G. Microbial colonization of prosthetic devices II. Scanning electron microscopy of naturally infected intravenous catheters. Zentralbl Bakteriol Mikrobiol Hyg [B] 1981 ; 173 : 293-299.

2. Peters G, Locci R. Pulverer G. Adherence and growth of coagulase-negative staphylococci on surfaces of intravenous catheters. $J$ Infect Dis $1982 ; 146: 479-482$.

3. Peters G. New considerations in the pathogenesis of coagulasenegative staphylococcal foreign body infection. $J$ Antimicrob Chemother 1988; 21 Suppl C: 139-148.

4. Peterson PK, Matzke G, Keane WF. Current concepts in the management of peritonitis in patients undergoing contin uous ambulatory peritoneal dialysis. Rev Infect Dis 1987 9: 604-612.

5. Peterson PK, Kovarik J, Gray DRP, Pence T, Keane WF. Coagulase-negative staphylococcal peritonitis a nemesis of CAPD. Zentralbl Bakteriol Mikrobiol Hyg 1987; Suppl 16: $159-165$.

6. Karchmer AW, Swartz MN. Infective endocarditis in patients with prosthetic heart valves. In: Kaplan EL, Taranta AV (eds) Infective endocarditis: an American Heart Association symposium. Monograph 52. Dallas, American Heart Association. 1977: 58-61.

7. Pascual A, Fleer A, Westerdaal NA, Berghuis M, Verhoef J. Surface hydrophobicity and opsonic requirements of coagulase-negative staphylococci in suspension and adhering to a polymer substratum. Eur J Clin Microbiol Infect Dis $1988 ; 7: 161-166$

8. Van Bronswijk H, Verbrugh HA, Heezius HCJM et al. Heterogeneity in opsonic requirements of Staphylococcus epidermidis : relative importance of surface hydrophobicity, capsules and slime. Immunology 1989; 67: 81-86.

9. Peterson PK, Wilkinson BJ, Kim Y et al. The key role of peptidoglycan in the opsonization of Staphylococcus aureus. $J$ Clin Invest 1978; 61 : 597-609. and 36.3 both on and close to the surface of $S$. epidermidis strain 354 .

In conclusion, our experiments have demonstrated a MAb (36.4) that reacts with a $220-\mathrm{Kda}$ band in immunoblots and shows complement-independent opsonic activity in phagocytosis studies with PMNLs and monocytes. We postulate that the presence of $\mathrm{F} c \gamma \mathrm{R} 1$ and $\mathrm{Fc} \gamma \mathrm{R} 2$ receptors on human monocytes is responsible for the higher uptake by these phagocytes. Furthermore, we have shown that MAb 36.4 is capable of generating the metabolic burst in human PMNLs by a complement independent mechanism. Future experiments will be directed at identification and biochemical characterisation of the antigen which appears to be important in the opsonic requirements of CNS.

10. Köhler G, Milstein C. Continuous cultures of fused cells secreting antibody of predefined specificy. Nature 1975 ; 256: $495-497$.

11. Fazekas de St. Groth S, Scheidegger D. Production of monoclonal antibodies: strategy and tactics. $J$ Immunol Methods $1980 ; 35$ : 1-21.

12. Shulman M, Wilde CD, Köhler G. A better cell line for making hybridoma secreting specific antibodies. Nature 1978 ; 276: 269-270.

13. Bradford MM. A rapid and sensitive method for the quantitation of microgram quantities of protein utilizing the principle of protein-dye binding. Anal Biochem 1976; 72: 248-254.

14. Laemmli UK. Cleavage of structural proteins during the assembly of the head of bacteriophage T4. Nature 170 227: $680-685$.

15. Voorhout WF, Leunissen-Bijvelt JJM, Leunissen JLM, Verkleij AJ. Steric hindrance in immunolabelling. J Micros 1986 141: $303-310$.

16. Böyum A. Isolation of mononuclear cells and granulocytes from human blood. Scand J Clin Invest 1968; 21 : 77-89.

17. Verbrugh HA, Peters R, Peterson PK, Verhoef J. Phagocytosis and killing of staphylococci by human polymorphonuclear and mononuclear leucocytes. J Clin Pathol 1978; 31 : 539 545.

18. Verhoef J, Peterson PK, Quie PG. Kinetics and staphylococcal opsonization, attachment, ingestion and killing by human polymorphonuclear leukocytes: a quantitative assay using $\left[{ }^{3} \mathrm{H}\right]$ thymidine labeled bacteria. J Immunol Methods 1977; 14: $303-311$.

19. Burnie J, Matthews RC. Mini-review: Immunoblot analysis: a new method for fingerprinting hospital pathogens. $J$ Immunol Methods 1987; 100: 41-46.

20. Burnie JP, Lee W, Matthews RC, Bayston R. Technical methods. Immunoblot finger-printing of coagulase negative staphylococci. J Clin Pathol 1988; 41: 103-110.

21. Clark LA, Easmon CSF. Opsonic requirements of Staphylococcus epidermidis. J Med Microbiol 1986; 22 : 1-7. 